Portland State University

PDXScholar

Engineering and Technology Management

Faculty Publications and Presentations

8-1-2015

\title{
Internal or External Knowledge: Which is More Important for the Performance of National Laboratories in Technology Latecomer Countries?
}

Pattravadee Ploykitikoon

Portland State University

Charles M. Weber

Portland State University, webercm@pdx.edu

Follow this and additional works at: https://pdxscholar.library.pdx.edu/etm_fac

Part of the Operations Research, Systems Engineering and Industrial Engineering Commons Let us know how access to this document benefits you.

\section{Citation Details}

Ploykitikoon, P., \& Weber, C. M. (2015, August). Internal or external knowledge: Which is more important for the performance of national laboratories in technology latecomer countries?. In Management of Engineering and Technology (PICMET), 2015 Portland International Conference on (pp. 1787-1797). IEEE.

This Article is brought to you for free and open access. It has been accepted for inclusion in Engineering and Technology Management Faculty Publications and Presentations by an authorized administrator of PDXScholar. Please contact us if we can make this document more accessible: pdxscholar@pdx.edu. 


\title{
Internal or External Knowledge: Which is More Important for the Performance of National Laboratories in Technology Latecomer Countries?
}

\author{
Pattravadee Ploykitikoon, Charles M. Weber \\ Department of Engineering and Technology Management, Portland State University, Portland, OR - USA
}

\begin{abstract}
The national laboratories in countries that are latecomers to advanced technological development are considered a significant source of scientific knowledge and technology for local industries that the national government deems strategic and for developing the country's infrastructure. This knowledge comes from both inside and outside the national laboratories. We investigate the relative impact of internal and external sources of knowledge on the performance of the national laboratories of a rapidly developing country, whose stated missions are 1) satisfying the needs of targeted local technology users; 2) commercialization of technology; and 3) developing a long-term $R \& D$ capability for the country. We conduct a survey-based study, which covers 208 recently completed R\&D projects that span three industries: biotechnology; electronics and computers; materials and nanomaterials. Our study finds that, regardless of mission, knowledge from external sources impacts performance more significantly than internal knowledge does. The impact on performance is greatest when knowledge from internal and external sources is used in conjunction. We consequently make the case for an open innovation policy for the national laboratories in technology latecomer countries and for implementing practices that enhance the capacity to absorb knowledge that flows into the national laboratories from external sources.
\end{abstract}

\section{INTRODUCTION}

In most countries, the national laboratories are considered a significant source of scientific knowledge and technology for targeted local industries that the national government deems strategic and for local public agencies that are engaged in developing the country's infrastructure [1], [2]. In countries that are technological latecomers, ${ }^{1}$ the national laboratories tend to lack the experience, expertise and financial resources to perform fundamental research, conduct and applied research and develop advanced technologies [3][5]. They consequently depend on external sources of knowledge much more than their counterparts in developed countries do [2], [6]-[12]. Knowledge from external sources has to be combined with knowledge that resides within the national laboratories for the national laboratories to perform the missions for which they were established. This mandate raises the following question of interest: Which is more important for the performance of national laboratories in

\footnotetext{
${ }^{1}$ According to Fagerberg and colleagues [3], technological latecomer countries such as Thailand, Indonesia, Chile and Pakistan are making efforts to advance both technologically and economically, but still lag behind countries such as South Korea, Taiwan and Singapore, which are approaching advanced stages of development.
}

technology latecomer countries-internal or external knowledge?

\section{BACKGROUND}

The national laboratories in technology latecomer countries tend to pursue the following three missions that the government of these countries considers critical: 1) adopt and adapt technology for benefits local industry and public agencies that develop national infrastructure, i.e., organizational entities that will henceforth be referred to as local technology users or LTUs [1], [2], [6]-[12]; 2) commercialize technology for financial benefit of the organizations within the national laboratories themselves [13]; and 3) retain and sustain technological capability to generate an experience base for the demands of the future of the country [2], [7]. To succeed at these three missions, the national laboratories need to deliver many successful R\&D projects; engage with external sources of knowledge for acquiring new knowledge; as well as establish and strengthen internal R\&D units or project groups as a source of internal knowledge that builds up team's capacity to absorb knowledge from outside the project group [14].

Knowledge that resides within the project group can be developed through deliberate project-internal learning activities (PILAs) [15]-[21] while the project is ongoing. Alternatively internal knowledge can be acquired by engaging in internal and external learning before the project begins. Such knowledge can be about the core technology to be developed in the project or about subject matter related to the context of the project [21]. Knowledge can also be brought into the project group by hiring [22] technical personnel that has extensive work experience pertaining to subject matter that is relevant to the project. Such experienced personnel can be "grafted" [22] from other R\&D units $(O R D U s)$ or project groups within the national laboratories, from local technology users or from foreignowned firms.

Knowledge can flow into a project group within the national laboratories directly, if the project group engages in external learning (e.g., [23]) with a variety of sources. These include ORDUs from inside the national laboratories [23]; LTUs [25]; local universities [26]; and international sources of knowledge such as foreign-owned firms and foreign universities [26]. External learning activities come in one of two flavors: contextual or vicarious [23]. Contextual Learning Activities (CLAs) consist of scanning the environment for information and ideas about competitors, customers and technological trends [23]-[28]. They enable 
group members to enhance their awareness of current events that are taking place outside their organization. By contrast, Vicarious Learning Activities (VLAs) consist of group learning through which an organization acquires second-hand experience about its ongoing project from experienced outsiders [20], [23], [28]-[31].

While internal and external learning have been studied extensively and discussed in the academic literature (e.g., [14]-[23], [28]-[31]), these phenomena have not been sufficiently investigated in the national laboratories of technology latecomer countries. Yet, it is in settings such as these that external and internal learning can have enormous practical impact because they directly influence national policy. In particular, policy makers in latecomer countries would want to know whether they should invest more in developing internal sources of knowledge or whether they should encourage engagement and new investment in external sources of knowledge to increase the performance of the national laboratories. This paper consequently addresses the following research question: What is the relative impact of internal and external knowledge on the performance of national laboratories in technology latecomer countries?

\section{DESCRIPTION OF RESEARCH}

To answer the research question from above, we performed an empirical study of external and internal learning in the national laboratories of a particular technology latecomer country, henceforth referred to as NLTLC. We chose NLTLC as a setting for this study because internal and external learning are observable at NLTLC and because achieving missions 1,2 and 3 from above is stated policy at NLTLC. We conducted a survey of 128 R\&D projects managers with the intent of identifying key factors related to external and internal knowledge and its impact on the performance of $R \& D$ projects. Thus, R\&D projects within NLTLC are the unit of analysis of our study. Our total sample size was $208 \mathrm{R} \& \mathrm{D}$ projects, which were completed in NLTLC less than two years before the survey was conducted. The survey covers three industries: biotechnology; electronics and computers; and materials and nano-materials. It was administered directly to project managers in a questionnaire. Due to strong support from the director of NLTLC and his executive team, we received a $100 \%$ response rate.

The survey contained questions and statements regarding input variables (IVs) and moderating variables (MVs). Input variables address knowledge inflows, whereas moderating variables pertain to knowledge that resides in or is generated within project groups. The project managers responded to questions regarding these variables on a 6-point Likert scale. Questions and statements pertaining to general information about NLTLC and output variables that assess the performance of projects were also included in the survey. They are detailed in tables in Appendix A.1 and Appendix A.2, respectively.
The output variable for mission 1 (OV1) measures the likelihood of doing another project with project group under study on a 6-point Likert scale. The lower sample size of 194 projects for OV1 results from respondents not being able to answer all questions in the survey. The output variable for mission 2 (OV2) is measured by the probability of commercializing a technology from a particular project. The output pertaining to mission 3, long-term R\&D capability, is measured by using three criteria: 1) the probability of generating at least one publication from a particular project $(\mathrm{OV} 3.1)$; 2) the probability of generating one item of intellectual property (patent or copyright) from the project (OV3.2); and 3) the versatility of technology developed as part of a project as measured by numbers of industry applications of that technology that the respondents could identify on a list (OV3.3) (see Appendix B). ${ }^{2}$

Appendixes A.3 and A.4 illustrate how the constructs under investigation relate to the codes for the input variables that were measured and the questions in the questionnaire to which they correspond. The table in Appendix A.3 details the constructs, the names of input variables and questions pertaining to contextual learning about other R\&D units within the NLTLC; local universities; international sources of knowledge; and local technology users. Appendix A.4 details constructs, variables and questions pertaining to vicarious learning with the same entities.

Appendixes A.5, A.6 and A.7 illustrate how the constructs under investigation relate to the codes for the moderating variables that were measured and the questions in the questionnaire to which they correspond. The table in Appendix A.5 details the constructs, the names of moderating variables and questions pertaining to prior knowledge [22], i.e. knowledge that resided within the project group before the project began. The table in Appendix A.6 does likewise for project-internal learning activities (PILAs). Appendix A.7 covers the prior educational experience of team members, which could have been accumulated at foreign or domestic universities, as well as prior work experience [21], which could have been accrued abroad, at local technology users or at other R\&D units within NLTLC.

Data analysis consisted of a factor analysis ${ }^{3}$ followed by five multiple regression models ${ }^{4}$ for each output variable. The factor analysis identified factors that pertained to NLTLC's

\footnotetext{
${ }^{2}$ Appendix B describes 25 potential choices of industry applications for OV3.3. The number of strategic programs in which the output of the project can be applied is translated into an ordinal scale that consists of the following six classes: 1 means the output could not be applied in any strategic program; 2 means the output could be applied in one strategic program; 3 means the output could be applied in two strategic programs, 4 means the output could be applied in three strategic programs, 5 means the output could be applied in 4 strategic programs, and 6 means the output could be applied in more than four strategic programs.

3 Extraction method: Principal Component Analysis. Rotation method: Varimax with Kaiser normalization.

${ }^{4}$ Stepwise backward was used for building regression models, because that approach "runs lower risk of missing a predictor that predicts the outcome than the forward method" ([32], pp. 160-161), and it works when there are many predictors in the model.
} 


\section{Proceedings of PICMET '15: Management of the Technology Age}

internal and external sources of knowledge. The five regression models assessed the relative impact of the factors on the performance of the national laboratories. Model 1, the knowledge inflow baseline, includes factors from outside the project group, only. Model 2.1, the project group baseline, contains factors from inside the project group, only. Model 2.2, the intra-organization baseline, includes factors from inside the national laboratories, i.e., project internal factors and factors pertaining to external learning from other R\&D project groups. Model 3, the integrated model, covers all factors from model 1 and 2.1. Model 4, the interaction model, includes almost ${ }^{5}$ all factors from model 1 and model 2, as well as their interactions.

The relative impact of internal knowledge and external knowledge on project performance was assessed by benchmarking the model's predictive power and the total variance that the different regression models explained. Benchmarking criteria include $\mathrm{R}^{2}$, Adjusted $\mathrm{R}^{2}$, and F-ratio for multiple regressions pertaining to OV1 and OV3.3. Logistic multiple regressions had to be run for OV2, OV3.1 and OV3.2, because these output variables were derived from binary data. The Cox \& Snell $\mathrm{R}^{2}$, the Nagelkerke's $\mathrm{R}^{2}$, the Chi-Square and the percentage correct are used for benchmarking the variance explained by and the prediction power of these regressions.

\section{RESULTS}

The factor analysis has identified 17 factors, which include all input variables and moderating variables under study (see Appendix C and Appendix D). (The label FIV is assigned to factors composed of input variables; the label MIV is assigned to factors composed of moderating variables.) The factors are orthogonal, so multi-collinearity problems (described in [32]) did not occur in the regressions that were subsequently performed. Cumulatively, the 17 factors explain $90 \%$ of the variance. The constructs of the first 11 factors are reliable, with Cronbach's alpha always being greater than 0.7. The last six factors report no Cronbach's alpha since they are individual variables.

The factor analysis could not identify a truly dominant factor or small group of factors that explain most of the variation. PILA is the most significant factor; the next five factors pertain to vicarious learning activity. The vicarious learning factors are followed by a group of five factors that are either associated with contextual learning or prior knowledge about the subject matter. The list of factors is closed out by six single variables that are either associated with prior experience of various kinds or prior knowledge about the core technology that is under development.

Table 1 displays the results of the regression exercise. It shows that the five output variables have different predictive

\footnotetext{
${ }^{5}$ The interaction model does not cover FIV8, contextual learning about other R\&D project groups within the national laboratories; FMV6, prior education at local universities; and FMV7, prior education at foreign universities.
}

power and explanatory power, and that the regression models that include knowledge inflows tend to have greater explanatory power than the ones that do not. Output variable OV3.2 - the probability of generating at least one patent from a project - clearly has the lowest predictive power of all five output variables. The Cox \& Snell $\mathrm{R}^{2}$ and the Nagelkerke's $\mathrm{R}^{2}$ are below 0.2 for models 1 through 4 , meaning that these models cannot explain $20 \%$ of the variance. In model 1 , the Chi-Square is not significant at the level of $p<0.05$. The remaining output variables -- OV1, OV2, OV3.1 and OV3.3 - have a relatively high explanatory power for models that involve knowledge inflow. However, models 2.1 and 2.2, which exclude all factors that are exogenous to the national laboratories, have a significantly lower explanatory power. When compared to model 1, models 2.1 and 2.2 are particularly weak indicators of user satisfaction, probability of commercialization and probability of publication.

Not surprisingly, the explanatory power of the regression models increases as more variables are added. However, the differences in explanatory powers vary significantly from model to model. Model 3, the integrated model, has a much greater explanatory power than models 1, 2.1 and 2.2; model 4 , the interaction model, has a slightly greater explanatory power than model 3. It should also be noted that for output variables OV1, OV2, OV3.1 and OV3.3, model 2.2, the intraorganization baseline, does not show much of an improvement over model 2.1, the project group baseline. Evidently, including knowledge inflows from other R\&D project groups in a regression model does not significantly increase the explanatory power of the model.

\section{CONCLUSIONS AND DISCUSSION}

The empirical study that has been described in this paper finds that, regardless of mission, knowledge from external sources impacts performance more significantly than internal knowledge does. The impact on performance is greatest when knowledge from internal and external sources is used in conjunction. We consequently try to make the case for an open innovation policy [15] for the national laboratories in technology latecomer countries and for implementing practices that enhance the capacity to absorb knowledge [14] that flows into the national laboratories from external sources. We find that our study has normative implications for management practice, which are denoted below.

Firstly, the factor analysis shows that, regardless of knowledge source, vicarious learning activities explain more of the observed variance than contextual learning activities. This implies that the national laboratories could benefit from implementing programs that enhance the ability of individual $\mathrm{R} \& \mathrm{D}$ project groups to learn vicariously, i.e., to engage in face-to-face meetings and develop personal relationships with personnel outside the group. 
2015 Proceedings of PICMET '15: Management of the Technology Age

TABLE 1. SUMMARY OF PREDICTIVE POWER OF MODELS 1, 2.1, 2.2, 3 AND 4.

\begin{tabular}{|l|c|c|c|c|c|}
\hline & $\begin{array}{c}\text { Model 1. } \\
\text { Knowledge } \\
\text { Inflow Baseline }\end{array}$ & $\begin{array}{c}\text { Model 2.1. } \\
\text { Project Group } \\
\text { Baseline }\end{array}$ & $\begin{array}{c}\text { Model 2.2. } \\
\text { Intra- } \\
\text { Organization } \\
\text { Baseline }\end{array}$ & $\begin{array}{c}\text { Model 3. } \\
\text { Integrated } \\
\text { Model }\end{array}$ & $\begin{array}{c}\text { Model 4. } \\
\text { Interaction } \\
\text { Model }\end{array}$ \\
\hline
\end{tabular}

Mission-1: User Satisfaction
\begin{tabular}{|l|r|r|r|r|r|}
\hline $\mathrm{R}^{2}$ & .469 & .069 & .069 & .571 & .703 \\
$\mathrm{R}^{2}$ adjust & .458 & .059 & .059 & .550 & .665 \\
$\mathrm{~F}$ & $41.705 * * *$ & $7.042 * *$ & $7.042 * *$ & $27.175^{* * *}$ & $18.385 * * *$ \\
No. & 193 & 193 & 193 & 193 & 193 \\
\hline$? \mathrm{R}^{2}$ adjust (based on model '2.1') & - & - & 0.000 & 0.491 & 0.606 \\
\hline
\end{tabular}

Mission-2: Probability of Commercializing a Technology

\begin{tabular}{|c|c|c|c|c|c|}
\hline Cox \& Snell $\mathrm{R}^{2}$ & 0.384 & 0.102 & .133 & 0.485 & .604 \\
\hline Nagelkerke's $\mathrm{R}^{2}$ & 0.512 & 0.136 & .177 & 0.648 & .807 \\
\hline Chi-square & $100.728 * * *$ & $22.419 * * *$ & $29.568 * * *$ & $138.714 * * *$ & $192.909 * * *$ \\
\hline Percentage correct & 80.3 & 66.3 & 69.7 & 86.1 & 92.3 \\
\hline No. & 208 & 208 & 208 & 208 & 208 \\
\hline ?Cox \& Snell R ${ }^{2}$ (based on model '2.1') & - & - & 0.031 & 0.383 & 0.502 \\
\hline ?Nagelkerke ${ }^{2}$ (based on model '2.1') & - & - & 0.041 & 0.512 & 0.671 \\
\hline
\end{tabular}

\begin{tabular}{|c|c|c|c|c|c|}
\hline Cox \& Snell $\mathrm{R}^{2}$ & 0.236 & 0.115 & .141 & 0.338 & 0.447 \\
\hline Nagelkerke's $\mathrm{R}^{2}$ & 0.329 & 0.161 & .197 & 0.472 & 0.625 \\
\hline Chi-square & $55.922 * * *$ & $25.390 * * *$ & $31.553 * * *$ & $85.665 * * *$ & $123.321 * * *$ \\
\hline Percentage correct & 78.8 & 73.1 & 74 & 81.3 & 86.1 \\
\hline No. & 208 & 208 & 208 & 208 & 208 \\
\hline ?Cox \& Snell R ${ }^{2}$ (based on model '2.1') & - & - & 0.026 & 0.223 & 0.332 \\
\hline ?Nagelkerke ${ }^{2}$ (based on model '2.1') & - & - & 0.036 & 0.311 & 0.464 \\
\hline
\end{tabular}

\begin{tabular}{|c|c|c|c|c|c|}
\hline Cox \& Snell R ${ }^{2}$ & .015 & .048 & .061 & .075 & 0.237 \\
\hline Nagelkerke's $\mathrm{R}^{2}$ & .020 & .065 & .083 & .102 & 0.323 \\
\hline Chi-square & 3.041 & $10.199 * *$ & $13.044 * *$ & $16.167 * *$ & $56.182 * * *$ \\
\hline Percentage correct & 62.5 & 65.9 & 63.9 & 63.9 & 72.1 \\
\hline No. & 208 & 208 & 208 & 208 & 208 \\
\hline ?Cox \& Snell R ${ }^{2}$ (based on model '2.1') & - & - & 0.013 & 0.027 & 0.189 \\
\hline ?Nagelkerke ${ }^{2}$ (based on model '2.1') & - & - & 0.018 & 0.037 & 0.258 \\
\hline
\end{tabular}

Mission-3.3: Versatility of Technology
\begin{tabular}{|l|r|r|r|r|}
\hline $\mathrm{R}^{2}$ & .091 & .058 & .102 & .149 \\
$\mathrm{R}^{2}$ adjust & .073 & .048 & .085 & .123 \\
$\mathrm{~F}$ & $5.099 * *$ & $6.256 * *$ & $5.777 * * *$ & $5.857 * * *$ \\
$\mathrm{No}$. & 207 & 207 & $5.056 * * *$ \\
\hline $\mathrm{R}^{2}$ adjust (based on model '2.1') & - & - & 207 & 207 \\
\hline
\end{tabular}

$* * * \quad$ Significant at the $\mathrm{p}<0.001$ level (2-tailed).

$* * \quad$ Significant at the $\mathrm{p}<0.01$ level (2-tailed).

* $\quad$ Significant at the $\mathrm{p}<0.05$ level (2-tailed).

Please note that '? $\mathrm{R}^{2}$ adjust', '?Cox \& Snell $\mathrm{R}^{2}$ ' and '?Nagelkerke $\mathrm{R}^{2}$, respectively denote the differences between models 4,3 and

2.2 , on the one hand and model 2.1, on the other hand, for the parameters ' $\mathrm{R}^{2}$ adjust', 'Cox \& Snell $\mathrm{R}^{2}$ ' and 'Nagelkerke $\mathrm{R}^{2}$ '.

Secondly, our study has shown that the probability of generating a patent (OV3.2) lacks explanatory power, which suggests that patenting is not a strong function of knowledge inflows. Other factors (perhaps economic incentives) drive the generation of a patent. These factors need to be identified and harnessed, if the national laboratories want to make the ability to generate patents a key component of the experience base that responds to the demands of the future of the country.

More importantly, our study finds that the differential in explanatory power between knowledge inflow baseline (model 1) and the project group baseline (model 2.1) was much greater than the one that was observed between the intra-organization baseline (model 2.2) and the project group baseline. This observation suggests that performance (as 
measured by user satisfaction, success at commercialization, the propensity for publication and versatility of technology) depends significantly more on knowledge inflow into the national laboratories [15], [26] than on knowledge exchanges between project groups within the national laboratories [24], [28]-[31]. This implies that the impact of collaborative efforts between R\&D project groups within the national laboratories on the performance of these groups is limited. The national laboratories under study must manage inflows from exogenous sources of knowledge to achieve significant improvements in performance.

It should be noted that the above differential in explanatory power was observed with statistical significance in all three industries under study. This suggests that the results from above may be generalizable across many industries.

Finally, the large differential between the integrated model and the interaction model on the one hand, and the baseline models on the other hand imply synergy between knowledge inflows and internal knowledge. As theory would predict [14], [33], related internal knowledge increases the capacity to absorb knowledge from the outside. The project groups within the national laboratories are thus well advised to accumulate relevant knowledge prior to the beginning of a project [21], hire ("graft") personnel with relevant knowledge [22], and engage in organizational learning activities within the project group [15]-[19].

Prior knowledge is an internal factor that tends to impact the relationship between knowledge inflows and organizational performance ([14], [34]-[38]). Prior knowledge includes "basic skills, a shared language, and knowledge of the most recent scientific or technological developments in a given field" ([14], p. 131). Grafting on new members is a process through which an organization can rapidly gain new knowledge that has not been previously available within the organization. It primarily consists of moving people with relevant knowledge, experience and expertise from one organization or project group to another and integrating them into the project group [22]. These people could come from abroad [39]-[43], from inside the country but outside the organization [22] or from within the organization but outside the project group [44]. Project internal learning activities help project group members learn from experience as they execute their own projects [23], [45], [46]. The activities typically include "asking questions, seeking feedback, sharing information, experimenting, and talking about errors" [23, p. 82]. PILAs also play an important role for project members to absorb external knowledge that they have gained from technology gatekeepers. These employees interact extensively with individuals and organizations outside their own [47], [48]. They consequently bring technology into an organization from the outside.

The study that has been described in this paper is subject to a few limitations that can be overcome by follow-on research. Firstly, the study investigated the relative impact of knowledge inflows and internal knowledge as a whole on the performance of R\&D project groups. It differentiates between the various sources of knowledge, but it does not determine how knowledge from particular sources affects the different criteria that have been established in this study. This limitation can be overcome extracting more data from the five regression models that have been run for this study. Secondly, this study is limited by the fact that it was conducted at the national laboratories of only one country, a latecomer to advanced technology. If the study were repeated in the national laboratories of other technology latecomer countries with similar results, then the results of this study may be generalizable to the national laboratories of other countries at similar levels of development. The study's generalizability could be enhanced even further, if the study were repeated at corporate laboratories and in the national laboratories of a variety of countries at different levels of technological development.

Conducting the follow-on research described in the previous paragraph may lead to significant contributions to theory. First and foremost, performing the recommended follow-on studies would characterize the impact of different forms of internal knowledge on the capacity to absorptive external knowledge from a variety of sources, which would contribute to an improved theoretical understanding of the absorptive capacity phenomenon. The follow-on research from above could also produce empirically grounded theory of how knowledge flows through national innovation systems and enhance the theoretical understanding of the role that the national laboratories play within their national innovation systems.

\section{ACKNOWLEDGEMENTS}

The material presented in this paper is based upon work supported by the National Science Foundation under Grant No. 0822062 (Enabling Timely Revolutions in Organizational Performance)

\section{REFERENCES}

[1] S. Gu, "Implications of National Innovation Systems for Developing Countries: Managing change and complexity in economic development," Discussion Papers, 1999.

[2] R. Mazzoleni and R. Nelson, "The roles of research at universities and public labs in economic catch-up," Research Policy, Vol. 36, No. 10, 2007, pp. 1512-1528.

[3] J. Fagerberg, M. Srholec, et al., "The competitiveness of nations: Why some countries prosper while others fall behind," World Development, Vol. 35, No. 10, 2007, pp. 1595-1620.

[4] UNCTAD, Transnational Corporations and the Internationalization of $R \& D$. New York and Geneva, United Nations Conference on Trade and Development, United Nations, 2005.

[5] UNESCO, Global investment in $R \& D$, Montreal, Canada, Institute for Statistics, United Nations Educational, Scientific and Cultural Organization, 2011.

[6] J. M. Utterback, "The role of applied research institutes in the transfer of technology in Latin America." World Development, Vol. 3, No. 9, 1975, pp. 665-673. 
[7] R. R. Nelson, National Innovation Systems: A Comparative Analysis, Oxford University Press, USA, 1993.

[8] L. Kim, "Stages of development of industrial technology in a developing country: a model." Research Policy, Vol. 9, No. 3, 1980, pp. 254-277.

[9] L. Kim, "National system of industrial innovation: dynamics of capability building in Korea," National Innovation Systems: A Comparative Analysis, R. R. Nelson, Oxford University Press, 1993, pp. 357-383.

[10] L. Kim, Imitation to Innovation: The Dynamics of Korea's Technological Learning, Harvard Business Press, 1997.

[11] P. L. Chang and C. W. Hsu, "The development strategies for Taiwan's semiconductor industry," IEEE Transactions on Engineering Management, Vol. 45, No. 4, 1998, pp. 349-356.

[12] P. Intarakumnerd, P. Chairatana, and T. Tangchitpiboon, "National innovation system in less successful developing countries: the case of Thailand," Research Policy, Vol. 31, No. 8-9, 2002, pp. 1445-1457.

[13] E. Arnold, H. Rush, J. Bessant and M. Hobday, "Strategic planning in research and technology institutes," $R \& D$ Management, Vol. 28, No. 2, 1998, pp. 89-100.

[14] W. M. Cohen and D. A. Levinthal, "Absorptive capacity: A new perspective on learning and innovation," Administrative Science Quarterly, Vol. 35, No. 1, 1990, pp. 128-152.

[15] H. W. Chesbrough, W. Vanhaverbeke and J. West, Open Innovation: Researching a New Paradigm, New York: Oxford University Press, 2006.

[16] L. Argote and E. Miron-Spektor, "Organizational learning: From experience to knowledge," Organization Science, Vol. 22, 2011, pp. 1123-1137.

[17] P. S. Adler and K. B. Clark, "Behind the learning curve: A sketch of the learning process," Management Science, Vol. 37, No. 3, 1991, pp. 267-281.

[18] R. E. Bohn, "Measuring and managing technological knowledge," Sloan Management Review, Vol. 36, No. 1, 1994, pp. 61-73.

[19] M. A Lapré, A. S. Mukherjee and L. N. van Wassenhove, "Behind the learning curve: Linking learning activities to waste reduction." Management Science, Vol. 46, No. 5, 2000, pp. 597-611.

[20] A. C. Edmondson, A. B. Winslow, R. M. J. Boehmer and G. P. Pisano, "Learning how and learning what: Effects of tacit and codified knowledge on performance improvement following technology adoption," Decision Sciences, Vol. 34, No. 2, 2003, pp. 197-224.

[21] L. A. Nemanich, R. T. Keller, D. Vera and W. W. Chin, "Absorptive capacity in R\&D project teams: A conceptualization and empirical test," IEEE Transactions on Engineering Management, Vol. 57, No. 4, 2010, pp. 674-688.

[22] Huber, G. P., "Organizational learning: The contributing processes and the literatures," Organization Science, Vol. 2, No. 1, 1991, pp. 88-115.

[23] Bresman, H., "External learning activities and team performance: A multi-method field study," Organization Science, Vol. 21, No. 1, 2010, pp. 81-96.

[24] D. G. Ancona and D. F. Caldwell, "Bridging the boundary: External activity and performance in organizational teams." Administrative Science Quarterly, Vol. 37, 4, 1992, pp. 634-665.

[25] E. von Hippel, The Sources of Innovation, Oxford University Press, New York, 1988.

[26] B. A. Lundvall, National Systems of Innovation: Toward a Theory of Innovation and Interactive Learning, Anthem Press, 2010.

[27] T. Allen, Managing the Flow of Technology: Technology Transfer and the Dissemination of Technological Information within the $R \& D$ Organization, Cambridge, Mass., MIT Press, 1977.

[28] M. T. Hansen, "The search-transfer problem: the role of weak ties in sharing knowledge across organization subunits," Administrative Science Quarterly, Vol. 44, No. 1, 1999, pp. 82-85.
[29] L. Argote, P. Ingram, J. M. Levine and R. L. Moreland, "Knowledge transfer in organizations: Learning from the experience of others," Organizational Behavior and Human Decision Processes, Vol. 82, No. 1, 2000, pp. 1-8.

[30] D. Epple, L. Argote and R. Devadas, "Organizational learning curves: A method for investigating intra-plant transfer of knowledge acquired through learning by doing," Organization Science, Vol. 2, No. 1, 1991, pp. 58-70.

[31] E. D. Darr and L. Argote, "The acquisition, transfer, and depreciation of knowledge in service organizations: Productivity in franchises." Management Science, Vol. 41, No. 11, 1995, pp. 1750-1762.

[32] A. P. Field, Discovering Statistics Using SPSS, SAGE Publications Ltd., 2005.

[33] S. A. Zahra and G. George, "Absorptive capacity: A review, reconceptualization, and extension," Academy of Management Review, Vol. 27, No. 2, 2002, pp. 185-203.

[34] G. Szulanski, "Exploring internal stickiness: Impediments to the transfer of best practice within the firm. Strategic Management Journal, Vol. 17, 1996, p. 27.

[35] B. Simonin, "Ambiguity and the process of knowledge transfer in strategic alliances," Strategic Management Journal, Vol. 20, No. 7, 1999 , p .595.

[36] S. F. Matusik, "An empirical investigation of firm public and private knowledge," Strategic Management Journal, Vol. 23, No. 5, 2002, pp. 457-467.

[37] G. Todorova, and B. Durisin, "Absorptive capacity: Valuing a reconceptualization," The Academy of Management Review, Vol. 32, No. 3, 2007, pp. 774-786.

[38] D. De Clercq and D. Dimov, "Internal knowledge development and external knowledge access in venture capital investment performance," Journal of Management Studies, Vol. 45, No. 3, 2008, pp. 585-612.

[39] X. Chen and C. Sun, "Technology transfer to China: alliances of Chinese enterprises with western technology exporters," Technovation, Vol. 20, No.7, 2000, pp. 353-362.

[40] Y. Gil, S. Bong and J. Lee, "Integration model of technology internalization modes and learning strategy: globally late starter Samsung's successful practices in South Korea," Technovation, Vol. 23, No. 4, 2003, p. 333.

[41] B. M. Hoekman, K. E. Maskus and K. Saggi, "Transfer of technology to developing countries: Unilateral and multilateral policy options," World Development, Vol. 33, No. 10, 2005, pp. 1587-1602.

[42] P. Ploykitikoon and T. U. Daim, "Technology transfer strategy: Review of successful research centres in the USA and Taiwan," International Journal of Technology, Policy and Management, Vol. 10, No. 3, 2010, pp. 227-238.

[43] A. B. Antal and E. M. Walker, "Organizational learning from Chinese returners: An exploratory study of the role of cross-cultural interactions," International Business and Management, 27, 2011." pp. 151-175.

[44] M. R. Haas and M. T. Hansen, "When using knowledge can hurt performance: the value of organizational capabilities in a management consulting company," Strategic Management Journal, Vol. 26, no. 1, 2005, pp. 1-24.

[45] A. C. Edmondson, "Psychological safety and learning behavior in work teams," Administrative Science Quarterly, Vol. 44, No. 2, 1999, pp. 350-383.

[46] S. Wong, "Distal and local group learning: Performance trade-offs and tensions," Organization Science, Vol 15, No. 6, 2004, pp. 645-656.

[47] T. J. Allen, "Communications, technology transfer, and the role of technical gatekeeper," $R \& D$ Management, Vol. 1, No. 1, 1971, pp. 1421.

[48] M. L. Tushman and R. Katz, "External communication and project performance: An investigation into the role of gatekeepers," Management Science, Vol. 26, No. 11, 1980, pp. 1071-1085. 
2015 Proceedings of PICMET '15: Management of the Technology Age

\section{APPENDIXES}

Appendix A.1: General information about projects in the national laboratories

\begin{tabular}{|l|l|l|l|}
\hline & \multicolumn{1}{|c|}{ Code } & N & \multicolumn{1}{|c|}{ Questions' order in questionnaire } \\
\hline Project ID & Project ID & & \\
Basic research & Basic_stg. & 208 & Q.1 R\&D strategy: Please classify the project by stage of \\
technological development by using the definitions from below. \\
Development and demonstration & App_stg. & 208 & \\
Bio technology & DD_stg. & 208 & \\
Material and Nano technology & Bio_tech. & 208 & Q.2 Please classify the project by technology type. \\
Embedded and software technology & MN_tech. & 208 & \\
Number of project group members & ES_tech. & 208 & \\
Number of PhD in project group & NO_mem & 208 & Q.4 Number of full-time members working on this project \\
& NO_PhD & 208 & $\begin{array}{l}\text { Q.5 Number of full-time members working on this project with } \\
\text { Ph.D. as the highest degree }\end{array}$ \\
\hline Number of MSc in project group & NO_MSc & 208 & $\begin{array}{l}\text { Q.6 Number of full-time members working on this project with } \\
\text { Masters as the highest degree }\end{array}$ \\
\hline
\end{tabular}

Appendix A.2: Questions Pertaining to Output Variables

\begin{tabular}{|c|c|c|c|}
\hline & Code & $\mathrm{N}$ & Questions' order in questionnaire \\
\hline Mission 1: User Satisfaction & OV1_Sat_LTUs & 194 & $\begin{array}{l}\text { Q.39 Based on the results of this project, do you think that the } \\
\text { targeted customers of this project will have another collaborative } \\
\text { project with your project group in the near future? }\end{array}$ \\
\hline $\begin{array}{l}\text { Mission 2: Probability of Commercialization of } \\
\text { Technology }\end{array}$ & OV2_Prob_Rev & 208 & $\begin{array}{l}\text { Q.40 Is there any income (in kind and in cash) expected to result } \\
\text { from this project? Please estimate expected income of this project. }\end{array}$ \\
\hline $\begin{array}{l}\text { Mission 3.1: Probability of Generating } \\
\text { Publication }\end{array}$ & OV3_1Prob_JrPub & 208 & 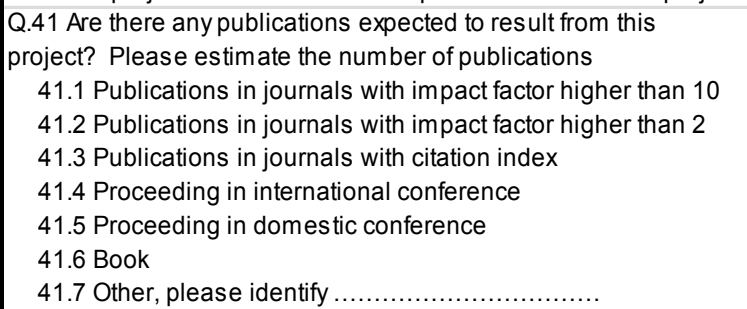 \\
\hline $\begin{array}{l}\text { Mission 3.2: Probability of Generating Intellectual } \\
\text { Property }\end{array}$ & OV3_2Prob_Patent & 208 & $\begin{array}{l}\text { Q.42 Are there any patents expected to result from this project? } \\
\text { Please estimate the number of patents that is expected to result }\end{array}$ \\
\hline Mission 3.3: Versatility of Technololgy & OV3_3Ver_Tech & 208 & $\begin{array}{l}\text { Q.3 Please identify as much as possible the strategic programs of } \\
\text { NLTLC in which the output of this project can be applied. }\end{array}$ \\
\hline
\end{tabular}

Appendix A.3: Questions Pertaining to Contextual Learning Activities [22] (Input Variables)

\begin{tabular}{|c|c|c|c|}
\hline & Code & $\mathrm{N}$ & Questions' order in questionnaire \\
\hline Contextual learning with other R\&D units 1 & IV1_ORDU_CLA1 & 208 & $\begin{array}{l}\text { Q.11 At least some members of our project group looked for } \\
\text { technical ideas in internal reports inside NLTLC. }\end{array}$ \\
\hline Contextual learning with local universities 1 & IV2_LocUniv_CLA1 & 208 & $\begin{array}{l}\text { Q.12 At least some members of our project group looked for } \\
\text { technical ideas in papers, reports and websites published by } \\
\text { universities inside the country. }\end{array}$ \\
\hline Contextual learning with inter sources 1 & IV3_InatSrc_CLA1 & 208 & $\begin{array}{l}\text { Q.13 At least some members of our project group looked for } \\
\text { technical ideas in papers, reports and websites that were } \\
\text { published by foreign universities and foreign-owned companies. }\end{array}$ \\
\hline Contextual learning with technology users 1 & IV4_LTUs_CLA1 & 208 & $\begin{array}{l}\text { Q.14 To understand the needs of our targeted customers, at least } \\
\text { some members of our project group looked for technical } \\
\text { requirements in industry newsletters, bulletins, websites and trade }\end{array}$ \\
\hline Contextual learning with other R\&D units 2 & IV5_ORDU_CLA2 & 208 & $\begin{array}{l}\text { Q.15 At least some members of our project group looked for data } \\
\text { on what other teams inside NLTLC were doing on similar or } \\
\text { complementary projects. }\end{array}$ \\
\hline Contextual learning with local universities 2 & IV6_LocUniv_CLA2 & 208 & $\begin{array}{l}\text { Q.16 At least some members of our project group looked for data } \\
\text { on what other teams at universities inside the country were doing } \\
\text { on similar or complementary projects. }\end{array}$ \\
\hline Contextual learning with inter sources 2 & IV7_InatSrc_CLA2 & 208 & $\begin{array}{l}\text { Q.17 At least some members of our project group looked for data } \\
\text { on what other teams at foreign universities and foreign-owned } \\
\text { companies were doing on similar or complementary projects. }\end{array}$ \\
\hline Contextual learning with technology users 2 & IV8_LTUs_CLA2 & 208 & $\begin{array}{l}\text { Q.18 At least some members of our project group looked for data } \\
\text { on what our targeted customers were doing on similar or } \\
\text { complementary projects. }\end{array}$ \\
\hline
\end{tabular}


2015 Proceedings of PICMET '15: Management of the Technology Age

\begin{tabular}{|c|c|c|c|}
\hline & Code & $\mathrm{N}$ & Questions' order in questionnaire \\
\hline Vicarious learning with other R\&D units 1 & IV9_ORDU_VLA1 & 208 & $\begin{array}{l}\text { Q.19 Experts within NLTLC talked to our project group about the } \\
\text { lessons learned from their past experiences. }\end{array}$ \\
\hline Vicarious learning with local universities 1 & IV10_LocUniv_VLA1 & 208 & $\begin{array}{l}\text { Q.20 Experts from universities inside the country talked to our } \\
\text { project group about the lessons learned from their past }\end{array}$ \\
\hline Vicarious learning with inter sources 1 & IV11_InatSrc_VLA1 & 208 & $\begin{array}{l}\text { Q.21 Experts from foreign universities and foreign-owned } \\
\text { companies talked to our project group about the lessons learned } \\
\text { from their past experiences. }\end{array}$ \\
\hline Vicarious learning with production units 1 & IV12_LTUsPU_VLA1 & 208 & $\begin{array}{l}\text { Q.22 Our targeted customers who have production units talked to } \\
\text { our project group about how to develop technology that is suitable } \\
\text { for their requirements. }\end{array}$ \\
\hline Vicarious learning within end users 1 & IV13_LTUsEU_VLA1 & 208 & $\begin{array}{l}\text { Q.23 Our targeted customers who are end users talked to our } \\
\text { project group about how to develop technology that is suitable for } \\
\text { their requirements. }\end{array}$ \\
\hline Vicarious learning with other R\&D units 2 & IV14_ORDU_VLA2 & 208 & $\begin{array}{l}\text { Q.24 At least some members of our project group talked to experts } \\
\text { within NLTLC about lessons learned from our past experiences. }\end{array}$ \\
\hline Vicarious learning with local universities 2 & IV15_LocUniv_VLA2 & 208 & $\begin{array}{l}\text { Q.25 At least some members of our project group talked to experts } \\
\text { within universities inside the country about lessons learned from } \\
\text { our past experiences. }\end{array}$ \\
\hline Vicarious learning with inter sources 2 & IV16_InatSrc_VLA2 & 208 & $\begin{array}{l}\text { Q.26 At least some members of our project group talked to experts } \\
\text { from foreign universities and foreign-owned companies about } \\
\text { lessons learned from our past experiences. }\end{array}$ \\
\hline Vicarious learning with production units 2 & IV17_LTUsPU_VLA2 & 208 & $\begin{array}{l}\text { Q.27 At least some members of our project group talked to our } \\
\text { targeted customers who have production units to determine ways } \\
\text { to improve our project. }\end{array}$ \\
\hline Vicarious learning with end users 2 & IV18_LTUsEU_VLA2 & 208 & $\begin{array}{l}\text { Q.28 At least some members of our project group talked to our } \\
\text { targeted customers who are end users to determine ways to }\end{array}$ \\
\hline
\end{tabular}

Please note that we observed two forms of vicarious learning with local technology users. One form involved LTUs that owned production units (PUs). The other form of LTU consisted of end users (EUs) without production units.

Appendix A.5: Questions Pertaining to Prior Knowledge [21]
\begin{tabular}{|l|l|c|l|}
\hline & \multicolumn{1}{|c|}{ Code } & (Moderating Variables) & \multicolumn{2}{|c|}{ Questions' order in questionnaire } \\
\hline Prior knowledge in core technology & MV1_PreKn_Core & 208 & $\begin{array}{l}\text { Q.7 How long was your group developing technology that is directly } \\
\text { relevant or useful to this project? }\end{array}$ \\
Prior knowledge in journal publications & MV2_PreKn_Jr & 208 & $\begin{array}{l}\text { Q.8 How many journal publications that were directly relevant or } \\
\text { useful to this project did your project group generate before this }\end{array}$ \\
Prior knowledge in patents & MV4_PreKn_Pat & 208 & $\begin{array}{l}\text { Q.10 How many patents that were directly relevant or useful to this } \\
\text { project did your project group generate before this project began? }\end{array}$ \\
Prior knowledge level of project group & MV14_PreKn_Lev & 208 & $\begin{array}{l}\text { Q.38 Prior to the start of our project, our project group generated a } \\
\text { lot of patents and publications that are relevant to this project. }\end{array}$ \\
\hline
\end{tabular}

Appendix A.6: Questions Pertaining to Project-Internal Learning Activities [14]-[18] (Moderating Variables)
\begin{tabular}{|l|l|c|l|}
\hline & \multicolumn{1}{|c|}{ Code } & Q & \multicolumn{1}{|c|}{ Questions' order in questionnaire } \\
\hline Project-internal learning activity 1 & MV5_PILA1 & 208 & $\begin{array}{l}\text { Q.29 Our project group took time to figure out ways to improve our } \\
\text { work process. }\end{array}$ \\
Project-internal learning activity 2 & MV6_PILA2 & 208 & $\begin{array}{l}\text { Q.30 Our project group took time to monitor our project's work } \\
\text { progress. }\end{array}$ \\
Project-internal learning activity 3 & 208 & $\begin{array}{l}\text { Q.31 Individuals within our project group spoke up to challenge } \\
\text { technical assumptions concerning issues that were under } \\
\text { discussion among members of our project group. }\end{array}$ \\
Project-internal learning activity 4 & MV7_PILA3 & $\begin{array}{l}\text { Q.32 The project group implemented suggestions made by team } \\
\text { members. }\end{array}$ \\
\hline
\end{tabular}

\section{Appendix A.7: Questions Pertaining to Prior Experience [20] (Moderating Variables)}

\begin{tabular}{|c|c|c|c|}
\hline & Code & $\mathrm{N}$ & Questions' order in questionnaire \\
\hline $\begin{array}{l}\text { Prior experience in education from international } \\
\text { sources of knowledge }\end{array}$ & $\begin{array}{l}\text { MV9_PrExp_- } \\
\text { Ed_InatSrc }\end{array}$ & 208 & $\begin{array}{l}\text { Q.33 At least one of our project group members has had very } \\
\text { extensive educational experience at a foreign university on subject } \\
\text { matter that is relevant to this project. }\end{array}$ \\
\hline $\begin{array}{l}\text { Prior experience in education from local sources } \\
\text { of knowledge }\end{array}$ & $\begin{array}{l}\text { MV10_PrExp_Ed_ } \\
\text { LocUniv }\end{array}$ & 208 & $\begin{array}{l}\text { Q.34 At least one of our project group members had very extensive } \\
\text { educational experience at a domestic university on subject matter } \\
\text { that is relevant to this project. }\end{array}$ \\
\hline $\begin{array}{l}\text { Prior experience in working from international } \\
\text { sources of knowledge }\end{array}$ & $\begin{array}{l}\text { MV11_PrExp_Wk_ } \\
\text { InatSrc }\end{array}$ & 208 & $\begin{array}{l}\text { Q.35 At least one of our project group members had very extensive } \\
\text { working experience abroad on subject matter that relevant to this }\end{array}$ \\
\hline $\begin{array}{l}\text { Prior experience in working with local technology } \\
\text { users }\end{array}$ & $\begin{array}{l}\text { MV12_PrExp_Wk } \\
\text { LTUs }\end{array}$ & 208 & $\begin{array}{l}\text { Q.36 At least one of our project group members had very extensive } \\
\text { working experience with our targeted customers on subject matter } \\
\text { that is relevant to this project. }\end{array}$ \\
\hline Prior experience in working with other R\&D units & $\begin{array}{l}\text { MV13_PrExp_Wk_ } \\
\text { ORDU }\end{array}$ & 208 & $\begin{array}{l}\text { Q.37 At least one of our project group members had very extensive } \\
\text { working experience with other projects within NLTLC on subject } \\
\text { matter that is relevant to this project. }\end{array}$ \\
\hline
\end{tabular}




\section{Appendix B: Versatility of Technology}

Question Q3 asks the following of the responding project manager: "To which of the following government-supported programs could the technology that is under development in your project group be applied?"
a. The Rice Program
b. The Tapioca Program
c. The Rubber Program
d. The Seed Program
e. The Plants for the Future Program
f. The Animal Production and Animal Health Program
g. The Food Innovation Program
h. The Newly Emerging Disease - Re-emerging Disease Program
i. Preventive, predictive and personalized medicine
j. Healthcare practice and medical devices
k. The Genotype Technology Program
1. Assistive Devices and Technologies for People with Disabilities and The Elderly Program
m. The Sustainable Environment Program
n. The Resource and Energy Efficiency Program
o. The Renewable Energy and New Technology Research Program
p. The Technology for Rural Development Program
q. The Bio-resources Program
r. The Hard Disk Drive Industry Research Program
s. The Air-conditioning and Refrigerator Industry Program
t. The Automotive and Automotive Parts Industry Program
u. Digital engineering
v. Sensor and intelligent system
w. Functional materials
$\mathrm{x}$. Service research and innovation
y. Other (please identify) 
Appendix C: Factor Analysis and Cumulative Variance Explained

Factor Analysis and Total Variance Explained

\begin{tabular}{|c|c|c|c|c|c|c|c|}
\hline \multirow[b]{2}{*}{$\begin{array}{c}\text { Factor } \\
\quad \#\end{array}$} & \multicolumn{2}{|c|}{ Initial Eigenvalues } & \multicolumn{2}{|c|}{\begin{tabular}{|l|} 
Rotation Sums of \\
Squared Loadings \\
\end{tabular}} & \multirow{2}{*}{$\begin{array}{l}\text { Factors of moderating variables (FMV) } \\
\text { Factors of independent variables (FIV) }\end{array}$} & \multirow{2}{*}{ Description } & \multirow{2}{*}{$\begin{array}{l}\text { Cronbach's } \\
\text { Alpha }\end{array}$} \\
\hline & \begin{tabular}{|c|c|}
$\%$ of \\
Variance
\end{tabular} & $\begin{array}{l}\text { Cumula- } \\
\text { tive } \%\end{array}$ & \begin{tabular}{|c|}
$\%$ of \\
Variance
\end{tabular} & $\begin{array}{l}\text { Cumula- } \\
\text { tive \% } \\
\end{array}$ & & & \\
\hline 1 & 16.212 & 16.212 & 10.383 & 10.383 & [FMV1_PILAs] & FMV1: Project internal learning activities & $(\alpha=.887)$ \\
\hline 2 & 14.298 & 30.510 & 7.005 & 17.389 & [FIV1_LTUsPU_VLAs] & FIV1: Engage with LTUsPU via VLAs & $(\alpha=.946)$ \\
\hline 3 & 11.461 & 41.972 & 6.678 & 24.067 & [FIV2_InatSrc_VLAs] & FIV2: Engage with InatSrc via VLAs & $(\alpha=.859)$ \\
\hline 4 & 7.003 & 48.975 & 6.525 & 30.592 & [FIV3_LocUniv_VLAs] & FIV3: Engage with LocUniv via VLAs & $(\alpha=.891)$ \\
\hline 5 & 6.306 & 55.281 & 6.445 & 37.037 & [FIV4_LTUsEU_VLAs] & FIV4: Engage with LTUsEU via VLAs & $(\alpha=.916)$ \\
\hline 6 & 5.325 & 60.605 & 6.435 & 43.473 & [FIV5_ORDU_VLAs] & FIV5: Engagement with ORDU via VLAs & $(\alpha=.867)$ \\
\hline 7 & 4.535 & 65.140 & 5.827 & 49.299 & [FIV6_InatSrc_CLAs] & FIV6: Engage with InatSrc via CLAs & $(\alpha=.816)$ \\
\hline 8 & 4.091 & 69.231 & 5.743 & 55.043 & {$[\mathrm{FMV} 2$ _PrKn_PJ] } & FMV2: Prior knowledge about the subject matter pertaining to the project & $(\alpha=.773)$ \\
\hline 9 & 3.358 & 72.590 & 5.295 & 60.337 & [FIV7_LTUS_CLAs] & FIV7: Engage with LTUs CLAs & $(\alpha=.769)$ \\
\hline 10 & 3.184 & 75.774 & 5.215 & 65.553 & [FIV8_ORDU_CLAs] & FIV8: Engagement with ORDU_CLAs & $(\alpha=.760)$ \\
\hline 11 & 2.866 & 78.640 & 5.061 & 70.613 & [FIV9_LocUniv_CLAs] & FIV9: Engage with LocUniv via CLAs & $(\alpha=.723)$ \\
\hline 12 & 2.336 & 80.976 & 3.587 & 74.200 & [FMV3_PrExp_Wk_LTUs] & FMV3: Prior experience in working with local technology users & - \\
\hline 13 & 2.225 & 83.201 & 3.504 & 77.704 & [FMV4_PrExp_Wk_ORDU] & FMV4: Prior experience in working with other R\&D units & - \\
\hline 14 & 1.983 & 85.184 & 3.353 & 81.057 & [FMV5_PrKn_Core] & FMV5: Prior knowledge in core technology & - \\
\hline 15 & 1.832 & 87.016 & 3.322 & 84.379 & [FMV6_PrExp_Ed_LocUniv] & FMV6: Prior experience in education from local sources of knowledge & - \\
\hline 16 & 1.668 & 88.684 & 3.287 & 87.666 & [FMV7_PrExp_Ed_InatSrc] & FMV7: Prior experience in education from international sources of knowledge & - \\
\hline 17 & 1.494 & 90.178 & 2.042 & 89.708 & [FMV8_PrExp_Wk_InatSrc] & FMV8: Prior experience in working at international sources of knowledge & - \\
\hline
\end{tabular}


Appendix D: How Variables Map onto Factors

\begin{tabular}{|c|c|c|c|c|c|c|c|c|c|c|c|c|c|c|c|c|c|}
\hline Factors & FMV1 & FIV1 & FIV2 & FIV3 & FIV4 & FIV5 & FIV6 & FMV2 & FIV7 & FIV8 & FIV9 & FMV3 & FMV4 & FMV5 & FMV6 & FMV7 & FMV8 \\
\hline Cronbach's Alpha & 0.887 & 0.946 & 0.859 & 0.891 & 0.916 & 0.867 & 0.816 & 0.773 & 0.769 & 0.76 & 0.723 & - & - & - & - & - & - \\
\hline Descriptive statistics: Min & -2.442 & -2.129 & -1.680 & -1.826 & -2.073 & -1.736 & -3.210 & -1.639 & -2.762 & -2.330 & -2.032 & -2.096 & -2.133 & -2.767 & -3.720 & -2.793 & -2.969 \\
\hline Descriptive statistics: Max & 2.341 & 2.386 & 2.928 & 3.046 & 2.488 & 3.260 & 2.175 & 2.393 & 2.569 & 3.947 & 3.939 & 2.247 & 2.502 & 1.697 & 1.990 & 1.686 & 3.082 \\
\hline \multicolumn{18}{|l|}{ Variables: } \\
\hline MV7_PILA3 & .899 & & & & & & & & & & & & & & & & \\
\hline MV8_PILA4 & .847 & & & & & & & & & & & & & & & & \\
\hline MV5_PILA1 & .805 & & & & & & & & & & & & & & & & \\
\hline MV6_PILA2 & .793 & & & & & & & & & & & & & & & & \\
\hline IV12_LTUsPU_VLA1 & & .909 & & & & & & & & & & & & & & & \\
\hline \multicolumn{18}{|l|}{ IV17_LTUsPU_VLA2 } \\
\hline IV16_InatSrc_VLA2 & & & .884 & & & & & & & & & & & & & & \\
\hline IV11_InatSrc_VLA1 & & & .883 & & & & & & & & & & & & & & \\
\hline IV10_LocUniv_VLA1 & & & & .907 & & & & & & & & & & & & & \\
\hline IV15_LocUniv_VLA2 & & & & .906 & & & & & & & & & & & & & \\
\hline IV13_LTUsEU_VLA1 & & & & & .903 & & & & & & & & & & & & \\
\hline IV18_LTUsEU_VLA2 & & & & & .892 & & & & & & & & & & & & \\
\hline IV14_ORDU_VLA2 & & & & & & .897 & & & & & & & & & & & \\
\hline IV9_ORDU_VLA1 & & & & & & .872 & & & & & & & & & & & \\
\hline IV3_InatSrc_CLA1 & & & & & & & .895 & & & & & & & & & & \\
\hline \multicolumn{18}{|l|}{ IV7_InatSrc_CLA2 } \\
\hline MV2_PrKn_- Jr & & & & & & & & .860 & & & & & & & & & \\
\hline MV14_PrKn_Lev & & & & & & & & .852 & & & & & & & & & \\
\hline IV4_LTUs_CLA1 & & & & & & & & & .875 & & & & & & & & \\
\hline IV8_LTUs_CLA2 & & & & & & & & & .761 & & & & & & & & \\
\hline IV1_ORDŪ_CLA1 & & & & & & & & & & .883 & & & & & & & \\
\hline IV5_ORDU_CLA2 & & & & & & & & & & .743 & & & & & & & \\
\hline \multicolumn{18}{|l|}{ IV2_LocUniv_CLA1 } \\
\hline IV6_LocUniv_CLA2 & & & & & & & & & & & .740 & & & & & & \\
\hline MV12_PrExp_Wk_LTUs & & & & & & & & & & & & .852 & & & & & \\
\hline MV13_PrExp_Wk_ORDU & & & & & & & & & & & & & .905 & & & & \\
\hline \multicolumn{18}{|l|}{ MV1_PrKn_Core } \\
\hline MV10_PrExp_Ed_LocUniv & & & & & & & & & & & & & & & .928 & & \\
\hline MV9_PrExp_Ed_InatSrc & & & & & & & & & & & & & & & & .889 & \\
\hline MV1 1 _PrExp_ Wk_InatSrc & & & .439 & & & & & & & & & & & & & & .503 \\
\hline$\%$ of Total Variance & 10.383 & 7.005 & 6.678 & 6.525 & 6.445 & 6.435 & 5.827 & 5.743 & 5.295 & 5.215 & 5.061 & 3.587 & 3.504 & 3.353 & 3.322 & 3.287 & 2.042 \\
\hline Cumulative $\%$ of Variance & 10.383 & 17.389 & 24.067 & 30.592 & 37.037 & 43.473 & 49.299 & 55.043 & 60.337 & 65.553 & 70.613 & 74.200 & 77.704 & 81.057 & 84.379 & 87.666 & 89.708 \\
\hline \multicolumn{4}{|c|}{ Extraction Method: Principal Component Analysis. } & & Rotation & Method: & $\operatorname{Varimax} \mathrm{v}$ & vith Kaiser & r Normal & ization. & & & & & & & \\
\hline
\end{tabular}

